\title{
Holck-sagen set med indiske øjne
}

Ravinder Kaur

\section{Niels Holck-sagen viser, at Danmark gerne udnyt- ter det nye indiske marked, men hænger fast $\mathrm{i}$ forestillinger om Indien som tilbagestående og brutalt. Og danskere mener, at Indien står i gæld til os for fortidens bistandshjælp}

16. august 2011 nedgraderede Indien officielt landets diplomatiske relationer til Danmark. Det kom efter fire års langsommelige forhandlinger og slagsmål ved domstole om den højprofilerede sag om den danske våbensmugler Niels Holck, alias Kim Davy.

Detaljerne er for velkendte i Danmark til at genfortælle her. Det er nok at slå fast, at sagen er blevet en større udfordring for de indisk-danske relationer. I historien om venskabelige diplomatiske bånd mellem Indien og Danmark er det første gang, at alvorlige misforståelser og mistillid har grebet begge parter. Sagen har ikke blot givet anledning til almindelige diplomatiske forhandlinger, men er snarere et resultat af langvarige juridiske slagsmål i Indien såvel som i Danmark om national sikkerhed og menneskerettigheder.

Hele fortællingen om dette juridiske og diplomatiske spil ligger uden for denne artikels rammer, så jeg vil begrænse mig til et enkelt aspekt, som er forblevet uudforsket. Det er det endnu uafklarede spørgsmål: Hvordan skal man behandle et Indien, der hastigt har udviklet sig fra et 'tredjeverdensland', der var afhængigt af international hjælp, til en større global spiller?

At den forandring er sket inden for et årtis korte periode, har betydet, at Danmark som mange andre vestlige lande endnu ikke har tilpasset sig den ændrede magtbalance.

Mens udenrigspolitiske dokumenter er ændret, og Indien nu rutinemæssigt kaldes 'en opstigende magt' - som er med i den højt besungne BRIK-gruppe og det asiatiske magt- 
center Kina og Indien - så er det stadig et eksotisk, romantisk og farligt sted i den vestlige forestillingsverden. Det er den dobbeltsidede og kontrastfyldte forestilling om Indien, som er bragt frem i lyset af Niels Holck-sagen. Længslen efter nye attraktive markeder og handelsmuligheder, som et neoliberalt Indien repræsenterer på den ene side og på den anden side den gamle frygt for et ukontrolleret og lovløst Indien, som siges er være hinsides folkeretten og menneskerettigheder. Bekymringen, der skabes af det tvetydige syn, er denne uløste konflikts kerne, som er mærkbar både i folkemunde og i politiske erklæringer.

Jeg vil her beskrive, hvordan sagen om våbennedkastningen er blevet rammet meget forskelligt ind $\mathrm{i}$ Danmark, og hvad det fortæller os om det indisk-danske forhold.

I Indien er 'Purulia våbennedkastningssagen', som den kaldes i folkemunde, hovedsagelig set gennem den nationale sikkerheds linser. Det er velkendt, at en stor våbenladning 17. december 1995 blev kastet ned fra et fly over Purulia i Vestbengalen af en lettisk besætning, den britiske våbenhandler Peter Bleach samt hjernen bag aktionen, Kim Davy (Niels Holck), hvis danske nationalitet først blev kendt i 2002, da det blev afsløret i en TV2 dokumentar.

Flyet var serviceret af en virksomhed i Karachi, der var kendt for bånd til Pakistans efterretningstjeneste. I indiske medier tog sagen en politisk drejning, da den blev fremstillet som en alvorlig krænkelse af indisk luftrum og intern sikkerhed.

At det viste sig, at udlændinge leverede våben til brug for opstand (det er stadig ret uklart, hvem som våbnene var tiltænkt $\mathrm{og}$ hvorfor) ses som en udfordring af Indiens suverænitet. Jagten på hjernen bag våbenoperationen, Niels Holck, er del af de igangværende forsøg på at finde en mening i begivenhederne $\mathrm{i}$ Purulia.

\section{Indien for retten}

I Danmark drejer sagen sig ikke om forbrydelser begået på indisk territorium af en dansk våbensmugler, men om indiske fængslers karakter og faren for menneskeretskrænkelser. Den danske debat, specielt i medier og domstole, er hovedsagelig fikseret på Indiens generalieblad om menneskerettigheder, torturkonventionen, forholdene i fængsler og mere kuriøst om styrken af Indiens demokratiske institutioner.

Kunne Indiens virkelig garantere, at Holck ikke ville blive udsat for tortur? Ville han $i$ realiteten få en fair retssag? Var der ikke tale om en sammensværgelse af korrupte ledere, rivaliserende politiske partier såvel som Indiens efterretningstjeneste, som ønskede at bruge en uskyldig person som Holck i deres egne magtspil? $\mathrm{Og}$ havde han, når alt kom til alt, ikke kun tjent de fattige og undertrykte ved at hjælpe dem til 
våben? Det er evident, at de forbrydelser, som Niels Holck har begået som han aldrig benægtede, men pyntede som humanitære handlinger - ikke længere er i fokus. Det er, som om Indien er stillet for retten i stedet.

Denne forskel imellem den indiske og danske opfattelse af sagen indikerer ikke blot en forskel i verdenssyn, men snarere det ubehag, som Indien er set med i Danmark. Indien er attraktivt for investeringer og business, men ses også som et farligt og lovløst sted. Det tema kunne ses gennem de sidste to år, hvor sagen fik central placering i danske medier. Jeg vil pege på følgende online-debat til at forstå konflikten. Efter nyhedshistorier om, at Indien kappede forbindelser til Danmark, begyndte en ophedet diskussion på danske nyhedssites. En deltager opsummerede de folkelige følelser: "Vi skal ikke udlevere folk til tortur! Indien er et uciviliseret samfund med korrupt politi, der tager imod bestikkelse. Det er ikke et demokrati eller retssamfund. Indien skulle hellere bruge tid på sine problemer med drab på pigespædbørn og frygtelige kastesystem".

Til spørgsmålet om indisk boykot påpegede en anden: "Ja, og det er så takken fra Indiens side for de mange år, vi har givet dem ulandsbistand".

De forskellige indlæg var fyldt med bemærkningen om den skrøbelige natur af Indiens politiske system og om, at man ikke kunne have tilstrækkelig tillid til den indiske stats garantier til at stille 'vores våbensmugler' for retten dér.

To indviklede temaer lå bag disse ytriger. For det første, at Indien er et hult demokrati, der ser ud som et moderne samfund, men nedenunder lurer den utæmmede og udisciplinerede praksis med et despotisk regimes barbariske praksis med vold og korruption.

Det er ikke et nyt standpunkt, men går i realiteten tilbage til kolonitiden, da vestlig imperialisme blev set som en gavnlig og moderniserende indflydelse, som kunne introducere de indfødte for liberale menneskelige værdier.

\section{Kolonimagtens gaver}

De moderne statsinstitutioner, demokratiets rammer og den indiske forfatnings blåstempling ses ofte fejlagtigt som 'imperiets gaver'. Denne dovne antagelse ses ofte hos dem, der ser bort fra den politiske tænknings rige historie i Indien og de store ideologiske forandringer, som fandt sted i Indien i begyndelsen af det 20. århundrede, og som skabte grundlaget for det moderne Indien.

Den fejlagtige opfattelse af det moderne Indien - og andre demokratiske lande i Asien og Afrika som efterligning af den 'originale' og derfor renere form for demokratier lever videre i bestemte kredse. I den verdensopfattelse forbliver $\mathrm{Eu}$ - 
ropa det ideologiske centrum og modernitetens hjemsted, som lande i den ikke-vestlige verden kun håber på at efterligne. Det er ikke usædvanligt at høre vestlige akademikere tale om problemerne ved at påtvinge et kunstigt system på mennesker, der ikke er 'naturligt' disponerede for idealer om demokrati og menneskerettigheder. Derfor vil Asien og Afrika altid blive set som de mindre oplyste, som kun kan håbe på 'at stige op' og blive lige som Europa.

Disse almindelige opfattelser bidrager også til at forklare, hvorfor og hvordan ellers meget velmenende organisationer som DANIDA rutinemæssigt giver udviklingsprogrammer betegnelser som 'god regeringsførelse', 'demokratisering' og 'menneskerettigheder', som specielt er rettet mod Asien og Afrika: at oplære ideer og praksis hos dem, som ikke naturligt er disponerede for Oplysningens arv.

Den opfattelse var også mærkbar i den offentlige debat, hvor Indien blev set som et eksempel på 'ikke perfekte' hule demokratier - med en ydre skal af demokrati, men tømt for andet end en utæmmet passion for vold og tortur. Det faktum, at Indien er verdens største demokratiske land, hvor meget af den sociale transformation er sket gennem politisk mobilisering og forfatningsreform, tages dårligt i betragtning.

I Sydasien er Indien det eneste land, som aldrig forfaldt til militærdiktatur - undtagen Indira Gandhis indførelse af to års undtagelsestilstand 1975 til 1977 - trods de utallige udfordringer af dets eksistens i de sidste seks og et halvt årti.

Også i dag oplever Indien massemobilisering imod korruption i statsapparatet - en form for mobilisering, som kun er mulig inden for et fungerende demokrati. Alligevel ses Indiens demokratiske generalieblad og dets indsat for respekt for loven som værdiløst.

\section{Taknemmelighedsgæld}

Det andet tema, som er forbundet hermed, er Indiens status som tidligere modtager af udviklingshjælp. De offentlige kommentarer peger på, at Indien skulle forblive taknemmelig over for Danmark, fordi det har modtaget udviklingshjælp derfra tidligere.

Sagen er, at danske hjælpeprogrammer, der startede i Indien i 1963, blev standset efter Indiens anmodning i 2003, og Indiens lån fra Danmark er betalt fuldt ud tilbage. Politikken bag, hvordan udviklingshjælp flyder og hvortil og i hvis interesse, har altid været en prekær sag. Mens nogle ser det som et moralsk projekt, der skal hjælpe undertrykte og marginaliserede medlemmer af menneskeheden op, ser andre det som et udenrigspolitisk instrument, der giver donorlande indflydelse på internationale anliggender. Magtbalancen mellem donorland og modtager er ret simpel og 
rå - donorlandene beslutter, hvilken slags udvikling, der er brug for, og modtagerne giver rum for eksperimenter, hvor programmerne kan føres ud i livet. Det sker trods snakken om 'partnerskab', der ofte fylder elegante brochurer og strategipapirer.

Mens bistandsforholdet mellem Indien og Danmark er udløbet, eksisterer resterne af magtubalancens sprog. Forventes det, at bistandsmodtagere, selv de tidligere, skal tillade borgere fra donorlande at begå forbrydelser på deres territorier? Skal lovenes forrang suspenderes under sådanne specielle omstændigheder? På sin vis flyder spredte debatter om bistandshjælp, humanitære motiver og tilsidesættelse af lov sammen i historien om Niels Holck.

I sine biografiske optegnelser (der er bredt tilgængelige på internettet) beskriver Holck sig selv som social aktivist, der forsøgte at hjælpe de fattige og undertrykte i Indien. Planlægningen og nedkastningen af våben bliver humanitær og ikke terror (der ellers har optaget den vestlige verden siden 9/11) i hans fortælling.

Bistandslande har altid været legepladser, hvor man fra tid til anden kan lege social retfærdighed - ikke kun de velmenende NGO'er, men også donorlandes private borgere.

Temaet 'det lovløse Indien' bliver tydeligt, når man ser, hvordan Niels Holcks sag står i skarp modstand til Camilla Broes sag. Hun blev anklaget for relativt små forbrydelser, som
USA havde bedt om at få hende udleveret for. De danske forsvarsadvokater brugte ikke forholdene i amerikanske fængsler til at plædere imod udlevering. Og ingen omtalte den udbredte brug af dødsdomme i USA's retssystem. USA's generalieblad om menneskerettigheder var heller ikke genstand for diskussion. Det er velkendt, at USA's fængsler gentagne gange er kritiseret af menneskerettighedsadvokater for at bruge langvarig isolation, der traumatiserer fanger og gør dem ude af stand til igen at blive integreret $\mathrm{i}$ samfundet.

Men disse træk blev aldrig del af mediekampagner. Camilla Broe blev sendt for retten i USA under samme betingelser, som ses som upassende for Niels Holck. Denne dobbeltmoral er blevet noteret og kommenteret meget i indiske medier i de seneste måneder.

\section{Et år senere}

Det er mere end et år siden, Indien nedgraderede de diplomatiske relationer. I den periode har Danmark indtaget det standpunkt, at det på grund af juridisk-tekniske forhold ikke kan gøre mere i sagen. Et af de få initiativer var et tilbud om at sende et hold advokater til Indien for at forklare, hvordan det danske retssystem fungerer. Der har også været diskussioner om at tilbyde at forklare Indien, hvordan de demokratiske institutioner - domstole, parlament 
og regering - arbejder i Danmark. Opfattelsen er, at Indien simpelthen ikke forstår, hvordan demokratier fungerer, og at det er den mangel på forståelse fra Indiens side, som er det virkelige problem.

I Indien ses den holdning i bedste fald som udtryk for arrogance, i værste fald som fravær af retfærdighed. I en leder med titlen 'En belæring om den hvide mands retfærdighed' i Indiens ledende avis The Hindu, beskrives Danmarks beslutning om ikke at udlevere Niels Holck som 'europæisk dobbeltmoral om menneskerettigheder'.

Ifølge domstole i Danmark kunne Niels Holck ikke sendes til Indien på grund af 'udbredt og systematisk brug af tortur'. Men artiklen understregede Danmarks deltagelse i CIAledede bortførelser og tortur af mistænkte terrorister. Den indiske avis påpeger, at reglerne er forskellige for hvide og brune terrorister, som behandlingen af Niels Holck har vist.

Holdningen $\mathrm{i}$ indiske medier fra venstre til højre har været kritisk over for både den indiske og den danske stat. Den danske holdning til menneskerettigheder er svækket i den indiske offentlighed af Danmarks aktive deltagelse i den USAledede krig imod terror. Kritikken af Danmark er blevet mere markant i takt med den danske blokering af vejen til retfærdighed i Indien.

Det indlysende er, at des længere denne vanskelige sag trækker ud, des sværere vil det blive for Danmark at rette op på forholdet til Indien.

Ravinder Kaur, ph.d., lektor og centerleder ved Institut for Tvarkulturelle og Regionale Studier.

Oversat fra engelsk af Vibeke Sperling. 